\author{
${ }^{\text {II.M. Babich }}{ }^{2}$ A.A.Baratova ${ }^{3}$ Z. K.Shomanova \\ ${ }^{1,3}$ Higher School of Natural Sciences of Pavlodar state pedagogical university \\ ${ }^{2}$ Nazarbayev Intellectual School in Pavlodar \\ Pavlodar, Kazakhstan
}

\title{
EXPLORING PRE-SERVICE CHEMISTRY TEACHERS' ATTITUDES TOWARDS LEARNING A SUBJECT IN ENGLISH IN KAZAKHSTAN
}

\begin{abstract}
This quantitative and qualitative mixed study aims to provide a glimpse into pre-service Chemistry teachers' attitudes and perceptions concerning content and language integrated learning. Study employed 120 first, second-and third-year students of State Pedagogical University who study Chemistry in English (after Kazakh and Russian), which is their L3. The findings revealed that at the beginning of their academic path, students develop a more negative attitude towards learning the subject in English for several reasons, namely, the uncertainty of their roles, being content or a language teacher, lack of confidence in language and teaching methods employed. However, it was further revealed that by their 3rd year at university, students gain awareness of the importance of learning content through English. They believe that, despite the various challenges they face while studying the subject, better educational and employment opportunities become available for those subject teachers who deliver their lessons in English.
\end{abstract}

Key words: attitudes, pre-service teachers, chemistry, CLIL, English, teacher-education

$$
\begin{gathered}
{ }^{1} \text { И.М. Бабич }{ }^{2} \text { А.А.Баратова }{ }^{3} \text { Ж.К. Шоманова } \\
{ }^{1,3} \text { Павлодар мемлекеттік педагогикалық университеті } \\
{ }_{2}^{2} \text { Назарбаев Зияткерлік мектептері, } \\
\text { Павлодар құаласы, ҚазақустанРеспубликасы }
\end{gathered}
$$

\section{БОЛАШАҚ ХИМИЯ МҰҒАЛІМДЕРІНІҢ ПӘНДІ АҒЫЛШЫН ТІЛІНДЕ ОҚУҒА ҚАТЫНАСЫН ЗЕРТТЕУ}

Аннотащия.
Бұл аралас сандық және сапалық зерттеу болашақ химия мұғалімдерінің пәндік интеграцияланған оқытуға деген түсінігі мен көзқарасы туралы түсінік алуға бағытталған. Зерттеуге Павлодар мемлекеттік педагогикалық университетінің химия пәнін ағылшын тілінде оқитын 120 бірінші, екінші және үшінші курс студенттері қатысты. Ағылшын тілі олар үшін L3 болып табылады (қазақ және орыс тілдерінен кейін). Зерттеу нәтижелері студенттердің химия пәнін ағылшын тілінде оқуға деген көзқарасының бірінші курстан үшінші курсқа өзгергенін көрсетті. Оқу жолының басында студенттердің интеграцияланған тілді үйренуіне теріс көзқарастары бар. Мұның басты себептері олардың өздерінің рөлдерін түсінбеуі: химия пәнінің мұғалімі немесе ағылшын тілі мұғалімі, ағылшын тілі мен оқыту әдістері туралы білімдерінің жоқтығы. Университеттегі үшінші курста студенттер ағылшын тілінде білім берудің маңыздылығы туралы біле бастайды. Болашақ мұғалімдердің химия пәнін ағылшын тілінде оқуда кездесетін түрлі мәселелеріне қарамастан, олардың білім алуына және жұмысқа орналасуына жақсы мүмкіндіктері бар депсанайды.

Түйін сөздер: қатынас, болашақ мұғалімдер, химия, CLIL, ағылшын тілі 


\author{
${ }^{1}$ И.М. Бабич ${ }^{2}$ А.А.Баратова ${ }^{3}$ Ж.К.Шоманова \\ ${ }^{1,3}$ Павлодарский государственный педагогический университет \\ ${ }^{2}$ Назарбаев Интеллектуальные школь \\ г. Павлодар, Казахстан
}

\title{
ИССЛЕДОВАНИЕ ОТНОШЕНИЯ БУДУЩИХ УЧИТЕЛЕЙ ХИМИИ К ИЗУЧЕНИЮ ПРЕДМЕТА НА АНГЛИЙСКОМ ЯЗЫКЕ
}

\begin{abstract}
Аннотащия
Это смешанное количественное и качественное исследование направлено на то, чтобы получить представление о восприятии и отношении будущих учителей химии к предметно-языковому интегрированному обучению. В исследовании приняли участие 120 студентов первого, второго и третьего курса Павлодарского государственного педагогического университета, которые изучают химию на английском языке. Английский язык является для них L3 (после казахского и русского языков). Результаты исследования показали изменение отношения студентов к изучению химии на английском языке от первого курса к третьему. В начале академического пути студенты имеют достаточно негативное отношение к языковому интегрированному обучению. Основными причинами этого являются непонимание ими собственной роли: учителя химии или учителя английского языка, неуверенность в знании английского языка и методах преподавания. К третьему году обучения в университете студенты узнают о важности изучения контента на английском языке. Они полагают, что, несмотря на различные проблемы, с которыми сталкиваются будущие педагоги при изучении химии на английском языке, перед ними открываются лучшие возможности для получения образования и трудоустройства.
\end{abstract}

Ключевые слова: отношение, будущие учителя, химия, CLIL, английский

Introduction. The integration of Kazakhstan into the global economic space requires specialists who are fluent in a foreign language and can effectively use it in everyday and professional communication.

Therefore, one of the top priorities in the development of education is the transition to a contentlanguage integrated learning (CLIL) and the training of multilingual teachers who are ready to provide instructions in three languages: Kazakh, as the state language, Russian, as the language of interethnic communication, and English, as the language of successful integration into the global economy. According to the State Program for the Development and Functioning of Languages in the Republic of Kazakhstan for 2011-2020[1], multilingual language policy should maintain the harmonious development of Kazakh and Russian, as well as promote English up to their level.

Wolff [2, p. 110]in his European Framework for CLIL teachers asserts that all teachers must be CLILtrained, namely, "they should integrate content and language teaching and become language-sensitive in their approach" .

Despite positive changes in the implementation of the strategic initiative of the English language development in some schools of the country and pedagogical higher educational institutions, the issue of systematic and high-quality teaching of Chemistry in English is still acute. The country's leading schools teaching Chemistry and other subjects in English have a problem of a shortage of trained specialists who do not implement $4 \mathrm{C}$ framework in their classrooms[3].

Most of the students who come to pedagogical apprenticeship every year at Nazarbayev Intellectual Schools still do not have a sufficient level of English, namely subject-specific language, and are not ready to organize communication in the classroom, give formative feedback to students, and timely respond to their cognitive needs.

1.2. Purpose of the study

Since the pedagogical university is the main source that supplies schools with qualified personnel, the Nazarbayev Intellectual School together with the Pedagogical University of Pavlodar (north-east of Kazakhstan) conducted a series of studies to understand the reasons for the insufficient level of students' readiness to teach Chemistry in English. The central aim of this mixed-methods study was to investigate the attitude of students enrolled in Chemistry educational programs toward studying the subject in English at the university. 
Methods. 2.1 Research design. This study is quantitative and qualitative mixed research. First, we conducted a survey among 1, 2- and 3-year cohorts followed by the qualitative interviews with open-ended and semi-structured questions to collect more in-depth information. As the focus of the study is on the attitudes, perceptions, thoughts, and feelings of pre-service teachers, the interview is the best tool that could be used to discover peoples' thoughts and reflections [4].

2.2. Participants

Overall 120 first, second and third-year students of the Pedagogical University, future chemistry teachers of secondary schools in Kazakhstan, were chosen as study participants.

The sample population of students is equal to their total population since there are120 students of 1-3 courses under the Chemistry educational program who are studying at the Pedagogical University in the 2019-2020 academic year. Therefore, the conclusions obtained in the course of the study can be unambiguously extended to the entire general population of students.

2.3. Instruments

In this study, we employed a questionnaire consisting of three sections. The first section collected preservice teachers' background information, while the next two sections were devoted to questions related to students' language proficiency and attitudes towards the learned subject. These are closed-ended questions with multiple choices. These questions are aimed at elucidating 1,2-and 3-year students' attitudes towards studying Chemistry in English. Items in questions were measured on a 5-point Likert scale and multiplechoice closed questions. Likert scale values range from one (strongly disagree) to 5 (strongly agree). To get more in-depth data, open-ended questions were also employed.

Furthermore, this study employed a qualitative interview-based approach, which is characterized by Creswell [5] as "an approach for exploring and understanding the meaning individuals or groups ascribe to a social or human problem" (p. 4), which is an ideal tool to investigate pre-service teachers' perceptions and attitudes regarding their experience of first, second and third year of learning Chemistry in English. Thus, twelve students, four out of each cohort, were randomly selected to participate in an open-ended semistructured interview:1 year of study (Participants 1,2,3 - Russian, 18 y.o., Participant 4 - Kazakh, 19 y.o.); 2 year of study (Participant 1 - Russian, 20 y.o., Participants 2,3,4 - Kazakh, 19 y.o.); 3 year of study (Participant 1,2,3 - Kazakh, 20 y.o., Participants 4 - Tatar, 21 y.o.)

\subsection{Data analysis}

The data collected were analyzed using the IBM SPSS Statistics 23. We used such indicators characterizing the distribution of variable values as: mean,variance and standard deviation

Data obtained from closed multiple-choice and open-ended questions was processed using frequency analysis: calculating a percentage of the total population.Analysis of variance (ANOVA) was used to compare the three samples. The average values of each sample were compared, and the statistical significance of the differences was determined.

Results. The study involved 120 students of the Faculty of Chemistry of the Pedagogical University. 33 of them are 1st-year students, 54 are 2nd-year students and 33 are 3rd-year students. Students are taught in groups with the Kazakh or Russian language of instruction and in English.

The native language for the vast majority of respondents is the Kazakh language (Table 1). 13.3\% of respondents use Russian and other languages as a means of communication. 
Table 1- Results of answers to questions A1-A3

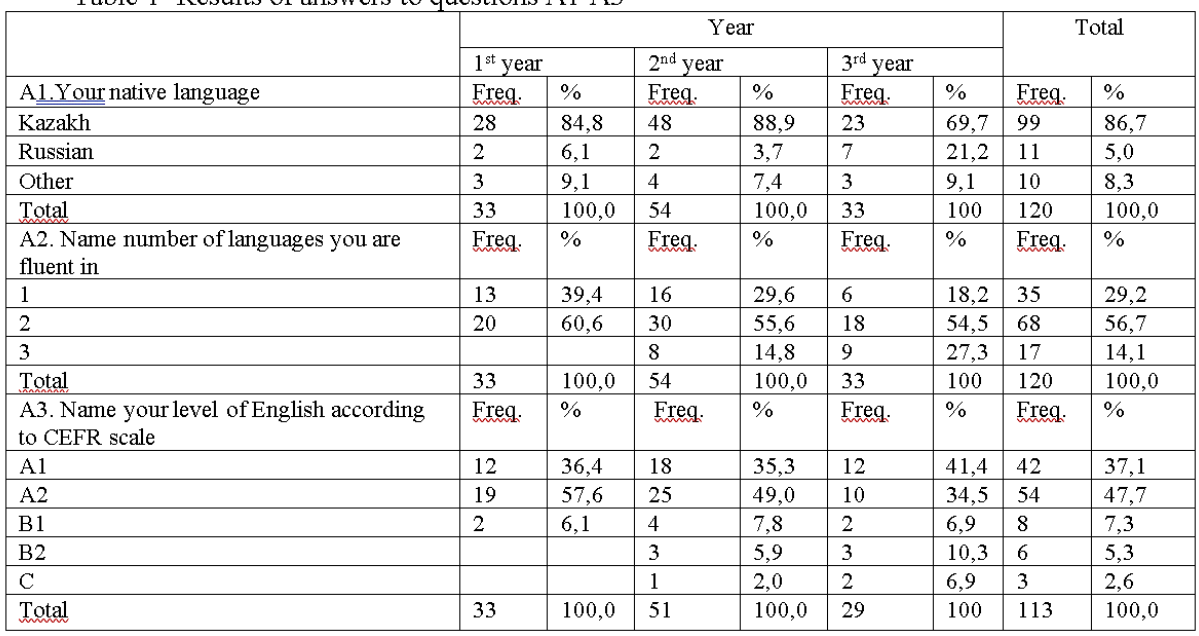

Although language is mainly the native language of students, more than half of the respondents are fluent in two languages, and 14\% are fluent in Kazakh, Russian and English. Moreover, the percentage of students speaking all three languages is increasing by the 3rd year.The percentage of respondents who speak only one language is reduced from the 1 st to the 3 rd year (Table 1).

Also, according to the data obtained from the third question, the percentage of students who have an English level of B2 and C1 increases from 1st to 3rd year. However, $84.8 \%$ of students have a fairly low level of development of the English language (A1 and A2).

The average value of students' opinions concerning the sufficiency of the level of the English language for understanding subject terminology gradually increases from year 1 to year 3 (Table 2).

Table 1 - Results of answers to question A4

\begin{tabular}{|c|c|c|c|c|c|c|c|c|c|c|c|}
\hline & \multicolumn{9}{|c|}{ Year } & \multirow{2}{*}{\multicolumn{2}{|c|}{ ANOVA }} \\
\hline & \multicolumn{3}{|c|}{$1^{\text {st }}$ year } & \multicolumn{3}{|c|}{$2^{\text {nd }}$ year } & \multicolumn{3}{|c|}{$3^{\text {rd }}$ year } & & \\
\hline & 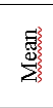 & 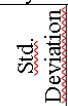 & 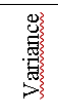 & 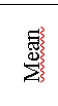 & 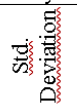 & 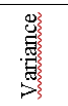 & 碳 & 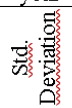 & 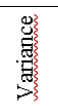 & $\mathrm{F}$ & Sig. \\
\hline $\begin{array}{l}\text { A4.I have sufficient } \\
\text { level of English to } \\
\text { understand subject } \\
\text { terminology }\end{array}$ & 1,88 & ,696 & ,485 & 2,76 & 1,243 & 1,545 & 3,79 & ,893 &, 797 & 28,7 &, 000 \\
\hline
\end{tabular}

But, on the Likert scale, it has a value much less than 5 (1.88 in the 1 st year and 2.76 in the second year), which is an indicator of respondents' disagreement with this statement. Only in the 3rd year the arithmetic mean is inclined towards the position of the Likert scale "I partially agree". However, the deviation from average is almost 1 (0.893). The greatest variation in opinions is observed among students of the 2 nd year. The smallest standard deviation and variance is observed in the 1st year students. 1st-year students are unanimous in their opinion that they do not have a sufficient level of English to understand subject terminology. In this and the subsequent analysis of the issues, the $\mathrm{F}_{\text {empirical }}$ is always greater than the $\mathrm{F}_{\text {critical }}$, and the statistical significance is $<0.05$. Therefore, the null hypothesis of the absence of statistically significant differences between the samples is rejected.

More than half of the respondents (53.3\%) chose to study Chemistry in their first (native) language(Fig. 1). However, $46.7 \%$ are ready to study science in two languages: native and English. If in the first year only $36.4 \%$ of students are ready to study the subject in two languages, in the second and third years they are already $42.6 \%$ and $63.6 \%$, respectively. 


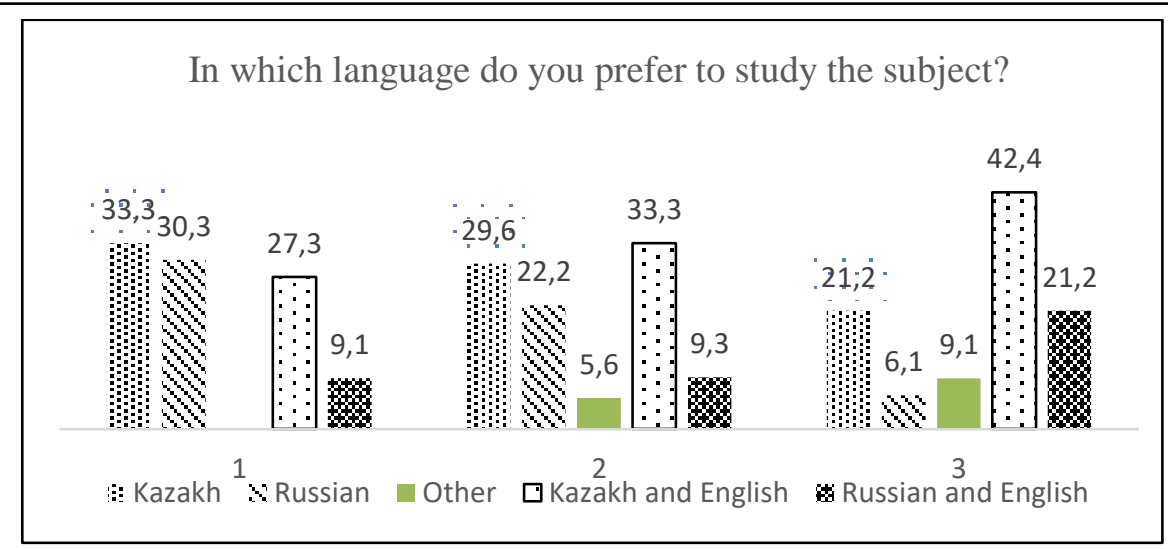

Figure 1 - Results of answers to question B1

It was identified that first and partially second-year students believe that studying Chemistry in English does not affect the quality of knowledge in the subject (Table 3). However, 3-year students have a reversed opinion. The average value of the Likert scale for this sample is significantly less than 5 and is inclined to the answer "Disagree".

Justifying their preference in choosing bilingual chemistry education, 3rd-year students consider that learning Chemistry with the use of English is more effective, as it will help to develop professional English, it is easier to remember specific terminology and develops 4 skills: reading, writing, speaking, listening. The majority of 1nd and 2rd-year students do not agree with this opinion.

Table2 - Results of answers to questions B2-B5

\begin{tabular}{|c|c|c|c|c|c|c|c|c|c|c|c|}
\hline & \multicolumn{9}{|c|}{ Year } & \multirow{2}{*}{\multicolumn{2}{|c|}{ ANOVA }} \\
\hline & \multicolumn{3}{|c|}{$1^{\text {st }}$ year } & \multicolumn{3}{|c|}{$2^{\text {nd }}$ year } & \multicolumn{3}{|c|}{$3^{\text {rd }}$ year } & & \\
\hline & 䙔 & 总壳 & 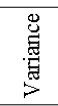 & 良 & 焉营 & 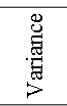 & $\stackrel{\text { 寻 }}{\sum_{\Sigma}}$ & 焉营 & 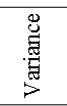 & 工 & $\stackrel{\infty}{\bar{n}}$ \\
\hline $\begin{array}{l}\text { B2. Learning Chemistry in } \\
\text { English does not affect } \\
\text { understanding the subject } \\
\text { content }\end{array}$ & 4,15 & ,939 &, 883 & 3,35 &, 677 & , 459 & 2,36 &, 783 &, 614 & 42,952 &, 000 \\
\hline $\begin{array}{l}\text { B3. Learning Chemistry } \\
\text { with English use is more } \\
\text { effective }\end{array}$ & 2,33 & ,645 &, 417 & 3,31 &, 773 & ,597 & 4,00 & ,661 & ,438 & 46,106 &, 000 \\
\hline $\begin{array}{l}\text { B4. It improves the ability } \\
\text { to communicate in English } \\
\text { in a professional context }\end{array}$ & 2,67 & ,595 &, 354 & 3,39 & 1,106 & 1,223 & 4,67 & ,595 &, 354 & 45,658 &, 000 \\
\hline $\begin{array}{l}\text { B5. Subject-specific terms } \\
\text { are remembered easier in } \\
\text { English }\end{array}$ & 2,30 &, 770 &, 593 & 3,06 & 1,280 & 1,638 & 4,27 & ,839 &, 705 & 30,552 &, 000 \\
\hline $\begin{array}{l}\text { B6. The content of lessons } \\
\text { helps me develop my } \\
\text { speaking, listening, reading } \\
\text { and writing skills in English }\end{array}$ & 2,27 &, 719 &, 517 & 3,04 & 1,149 & 1,319 & 4,15 & 1,004 & 1,008 & 29,149 &, 000 \\
\hline
\end{tabular}

Discussion. A decrease in the proportion of respondents who speak only one language (table 1) may be the result of increasing students' motivation to learn English and / or organizing consistent work at the university to develop English. This decrease can only be associated with the development of English speaking skills in 3rd year students, since it is English that unites students studying Kazakh or Russian. We believe that the low level of the English language is the reason for the negative attitude of first-year students to studying chemistry in English (Table 2).

Our assumption of reluctance to study Chemistry in English was confirmed (Fig. 1). None of the respondents chose to study the subject in English. The number of respondents who have chosen bilingual education increases by the third year.We can explain this by the fact that $3 \mathrm{rd}$ year students begin to understand the role of the English language in their future professional activities.

The distribution of answers between years in accordance with Table 3 is possible as a result of the fact that students of the 1st and 2nd courses do not have sufficient experience in studying chemistry in English at the university. As for the 3rd year students, they still have insufficient level of English proficiency (despite the positive dynamics(Fig. 1)) and, therefore, they experience difficulties with the content of the subject. 
Responses to open-ended interview questions allowed to derive clear-cut reasons that affected preservice teachers' attitudes to learning Chemistry in English.

Finding 1 - first and second-year students' uncertainty towards

Pre-service teachers at the beginning of their university life feel uncertain towards their self as teachers and subject they would teach in the future. This uncertainty stems mostly from "dual roles they have to take, either a subject teacher or an English language teacher" (Participant 3). As Mehisto, Frigols-Martín, \& Marsh [6] state it is difficult for them to perceive themselves as "integrated teachers". Lack of clarity of roles determines their reluctance to learn English as they prioritize the content of their subject over a foreign language. They feel as if they "miss the most of essential subject content due to English" which they do not know sufficiently (Participant 1).

Finding 2 - lack of appropriate recourses to meet their needs

Another reason that appeared from open-ended questions was in most parts, a complaint towards lack of necessary recourses, both human and material, to study Chemistry in English. They acknowledge that "there is no textbook to study Chemistry" which would be adapted for 1 and 2nd year-students (Participant 2). Another student raised an issue of "language environment" (Participant 5), stating that without native speakers, who are both subject and English-speaking teachers, it is a long and daunting task. Another recourse is English itself. They feel more than unconfident using English, not to mention, learning science in this language. Similarly, Dalton-Puffer [7] suggests that fear of lower language skills may eventually lead to a poorer understanding of the subject matter. A quarter of participants admitted that they "cannot understand main chemical concepts and processes in English" (Participant 5), which makes it difficult to become a subject teacher in the future. As was already mentioned in the 90s, Snow, Met \& Genesee [8] claim that any scientific topic requires both content and language essential to grasp this content, it is still relevant nowadays [2].

Theme 3 - collaboration is a key

By their 3rd year of study, students try to find various ways out to develop language. An overwhelming part of students mentioned that they had created a network of like-minded students with alike issues, which helped them enhance their skills. This network even spanned abroad. Apart from collaborating with language students from their cohort, study participants mentioned that they managed to find and keep contact with international students from near and far abroad. Those students who took part in the exchange program could successfully get oriented and navigate others (participants 7,9). The shortage of content teachers proficient in English, the absence of appropriate textbooks and methodology in lecture rooms, forced pre-service teachers to establish a community where members would support each other. As Coyle et al.[3, p. 17] point out, "success in CLIL mostly depends on the collaboration between content teachers", students, sitting at the university desk, already realized the necessity to cooperate not only with their peers but also with other language students, future L1, L2, and foreign language teachers. As it is well reflected in Gardner and Lambert [9, p. 132] "a sincere and personal interest in the people and culture represented by the other group" . Intending to develop their skills, pre-service teacher-linguists share their expertise and knowledge.

Theme 4 - extrinsic and intrinsic motivation (opportunities)

Another outcome that could be derived from interviewing study participants was the fact that by 3rd year of studying, pre-service teachers understand all benefits that they can reap from being a languageproficient content teacher. In their book about motivation in learning a foreign language, Lasagabaster, Doiz\& Sierra [10, p. 13]state that besides a goal, a vision which includes "strong sensory elements: tangible images related to achieving the goal" These tangible images of receiving a Diploma of a highly proficient content teacher and earning "Bolashak scholarship to further education in one of the top-tier international universities" (participant 10) was a pushing factor in learning the language. The only requirement that hinders most candidates in winning this state grant is language proficiency tests. Therefore, having such "tangible images" and striving for them is what makes pre-service teachers juggle between learning content and language simultaneously at the university desk. Another tangible incentive to learn the subject in English was artificially created by the government, which was mentioned by Participant 5 , which is a bonus to salary that subject teachers get at schools if they possess no less than IELTS 6.5 and teach a subject in English. This also proves to be a factor creating a positive attitude to CLIL and learning Chemistry in English.

Conclusion. The purpose of this study was to identify pedagogical university students' attitudes to the study of Chemistry in English. The results of the analysis showed that all students are not ready to study Chemistry only in English. However, their understanding of the importance of developing subject-specific English is growing from the first to the third year with an increase in the level of development of the respondents' language competencies. A sufficiently high percentage of preferences in bilingual education 
allows us to conclude that students accept English as a means of learning and see in bilingualism the possibility of developing language competencies, chemical English, studying abroad and earning higher salaries. Understanding of this comes gradually to third-year students.

The results of the study allow us to see a positive trend in the change in the attitude of students to the study of Chemistry with the use of English and first languages. However, the reasons for the negative attitude of students in courses 1 and 2 to study the subject in English require further research, which we will continue.

\section{References:}

1. State Program for the Development and Functioning of Languages in the Republic of Kazakh-stan for 2011-2020. Astana, 2010.

2. Wolff D. The European Framework for CLIL Teacher Education // Synerg. Ital. -2012. -Vol. 8. -P. 105-116.

3. Coyle D., Holmes B., King L. owards an intergrated curriculum: CLIL National Statement and Guidelines. / Coyle D., Holmes B., King L. -London: Languages Company, 2009. -44 p.

4. Patton M. Qualitative Research \& Evaluation Methods. 4th ed. / Patton M. -SAGE Publications, Inc, 2014. $-832 p$.

5. Creswell J. Research Design: Qualitative, Quantitative, and Mixed-Method Approaches. 2009.

6. Mehisto P., Marsh; D., Frigols M.J. Uncovering CLIL : content and language integrated learning in bilingual and multilingual education./ Mehisto P., Marsh; D., Frigols M.J.- Oxford : Macmillan Educatio, 2008. - $238 \mathrm{p}$.

7. Dalton-Puffer C. Discourse in Content and Language Integrated Learning (CLIL) Classrooms. Amsterdam: John Benjamins Publishing Company, -2007. -Vol. 20.

8. Snow M.A., Met M., Genesee F. A Conceptual Framework for the Integration of Language and Content in Second/Foreign Language Instruction // TESOL Q. -1989. -Vol. 23, № 2. -P. 201.

9. Gardner R.C., Lambert W.E. Attitudes and motivation in second-language learning./ Gardner R.C., Lambert W.E. - Rowley. Massachusetts: Newbury House Publishers, 1972.

10.Lasagabaster D., Doiz A., Sierra J.M. Motivation and foreign language learning: From theory to practice./Lasagabaster D., Doiz A., Sierra J.M.- Amsterdam: John Benjamins. Amsterdam: John Benjamins, 2014. - $190 \mathrm{p}$. 